\section{Temperature Requirements for the Storage and Germination of Delphinium $\times$ cultorum Seed}

\author{
William J. Carpenter \\ Department of Environmental Horticulture, Institute of Food and \\ Agricultural Sciences, University of Florida, Gainesville, FL 32611 \\ Joseph F. Boucher \\ Department of Statistics, Institute of Food and Agricultural Sciences, \\ University of Florida, Gainesville, FL 32611
}

Additional index words. cold pretreatment, seed desiccation, relative humidity

Abstract. Delphinium seed germination was about equal in light or darkness. Seed total germination percentages were highest and about equal at constant 15 or $20 \mathrm{C}$ and alternating $(12 \mathrm{~h}) 10 / 20 \mathrm{C}, 15 / 25 \mathrm{C}$, or $20 / 30 \mathrm{C}$. The most rapid and uniform germination generally occurred at constant $20 \mathrm{C}$. Storing seeds dry at $2 \mathrm{C}$ for 3 weeks before germination reduced the days to $50 \%$ of final germination $\left(T_{50}\right)$ and between $10 \%$ and $90 \%$ germination $\left(T_{90}-T_{10}\right)$ but did not increase total germination. The seeds had only limited desiccation tolerance, with 'Magic Fountains Lavender' having declining germination percentages at moisture contents below 7.0\% and 'Magic Fountains Lilac' below $6.7 \%$. Seeds tolerated storage at low, nonfreezing or subzero temperatures, but cultivar responses differed. 'Magic Fountains Lavendar' had progressively lower germination percentages as storage temperatures declined from 5 to $-20 \mathrm{C}$, while 'Magic Fountains Lilac' germination increased. The relative humidity (RH) and temperature that delphinium seed received during long-term storage influenced germination. Germination after seed storage at $5 \mathrm{C}$ was higher, earlier, and more uniform than after $\mathbf{1 5}$ or $25 \mathrm{C}$ storage. The highest total germination percentages occurred following seed storage at $5 \mathrm{C}$ and $30 \%$ to $50 \% \mathrm{RH}$, the shortest $\mathrm{T}_{50}$ from $35 \%$ to $55 \% \mathrm{RH}$, and shortest spans $\left(\mathrm{T}_{90}-\mathrm{T}_{10}\right)$ from $25 \%$ to $50 \%$ RH.

Recently introduced dwarf pacific types of Delphinium $\times$ cultorum that are compact and early flowering have been gaining acceptante as bedding plants. Commercial producers need rapid and uniform germination from direct seeding in propagation trays, but only limited research has been conducted on the germination of delphinium seed. Post (1942) found little germination above 13C, while the yearbook of agriculture (U.S. Dept. of Agriculture, 1961) reported 1.5 to $21 \mathrm{C}$ as best, and Holcomb and Beattie (1990) recommended $21 \mathrm{C}$ medium and $27 \mathrm{C}$ air temperatures. Ball (1985) recommended that dry seed be chilled at $2 \mathrm{C}$ for 2 weeks before sowing for improved germination. Recommendations for delphinium seed storage appear to be lacking. Our research objectives were to determine the need for light or darkness during germination, to compare temperatures during germination, and measure the effects of seed chilling, desiccation, and relative hu-

Received for publication 6 Dec. 1991. Accepted for publication 13 Apr. 1992. Florida Agriculture Experiment Station Journal Series no. R-01948. We acknowledge the seed source and assistance of Dana Richards, Bodgers Seeds, Lompoc, Calif. This research was partially sponsored by a grant from the Bedding Plants Foundation, P.O. Box 27241, Lansing, MI 48909. The cost of publishing this paper was defrayed in part by the payment of page charges. Under postal regulations, this paper therefore must be hereby marked advertisement solely to indicate this fact. [(trichloromethyl)thio] -1- $H$-isoindole-1,3 (2 $H$ )-dione (captan) after receipt on 9 Aug. All treatments contained four 100-seed replicates, with replicates germinated in individual $9-\mathrm{cm}$ petri dishes on double layers of Whatman No. 1 filter paper moistened with $6 \mathrm{ml}$ of distilled water (DW). Seeds were germinated in incubators (Stults Scientific Engineering Corp., Springfield, Ill.) at constant or 12-h alternating temperatures. In each study, germination counts were made daily of seeds with radicle protrusion through the testa. Total germination percentages $(\mathrm{G})$, days to $50 \%$ of final germination $\left(\mathrm{T}_{50}\right)$, and germination span in number of days between $10 \%$ and $90 \%$ germination $\left(\mathrm{T}_{90}-\mathrm{T}_{10}\right)$ were calculated as described by Furutani et al. (1985).

Germination temperature. 'Magic Fountains Lavender' and 'Magic Fountains Lilac' seeds were stored dry at 2 or $25 \mathrm{C}$ for 3 weeks before germination in darkness at constant $15,20,25$, or $30 \mathrm{C}$. In a second study, seeds stored at $2 \mathrm{C}$ for 6 weeks were germinated in dark incubators at 12 -h alternating temperatures of $10 / 20 \mathrm{C}, 15 / 25 \mathrm{C}$, or $20 / 30 \mathrm{C}$. The design for both studies was a randomized block with data tested by means of analysis of variance (ANOVA); Tukey's HSD multiple-comparison procedure was used to compare alternating temperatures.

Seed moisture content. Four replications of 100 seeds for each treatment were weighed, placed in 9-cm open petri dishes, and dehydrated for $6,12,24,48,72$, or $96 \mathrm{~h}$ in $40 \mathrm{C}$ forced-draft ovens. Following dehydration, seeds of each replication were reweighed and immediately sealed in screwcapped 10-ml glass vials, 100 seeds per vial, and stored at $2 \mathrm{C}$ for 3 weeks. After storage, seeds were reweighed and germinated at constant 20C. Germination data were analyzed by means of ANOVA and polynomial regression analysis. When the seeds were received, four 100-seed lots of each cultivar midity (RH) during seed storage.

Seed handling and germination procedures. Seeds of 'Magic Fountains Lavender' and 'Magic Fountains Lilac' used in all studies were harvested by Bodger Seeds, Lompoc, Calif., on 23 July 1990; air-dried for 10 days; then milled before shipment. Seeds were dusted with3 $\alpha, 4,7,7$ de trahydro-2-

Table 1. Comparison of delphinium germination at constant temperatures using seed stored for 3 weeks at 2 or $25 \mathrm{C}$.

\begin{tabular}{|c|c|c|c|c|c|}
\hline \multirow[b]{2}{*}{ Cultivar } & \multirow{2}{*}{$\begin{array}{l}\text { Storage } \\
\text { temp } \\
\left({ }^{\circ} \mathrm{C}\right)\end{array}$} & \multicolumn{4}{|c|}{ Germination $^{2}$} \\
\hline & & $\begin{array}{l}\text { Temp } \\
\left({ }^{\circ} \mathrm{C}\right)\end{array}$ & Percenty & $\begin{array}{c}\mathrm{T}_{50}{ }^{y} \\
\text { (days) }\end{array}$ & $\begin{array}{c}\mathrm{T}_{90}-\mathrm{T}_{10}{ }^{\mathrm{y}} \\
\text { (days) }\end{array}$ \\
\hline \multirow[t]{2}{*}{$\begin{array}{l}\text { Magic Fountains } \\
\text { Lavender }\end{array}$} & 2 & $\begin{array}{l}15 \\
20 \\
25 \\
30\end{array}$ & $\begin{array}{l}78 \mathrm{a} \\
75 \mathrm{a} \\
70 \mathrm{a} \\
37 \mathrm{~b}\end{array}$ & $\begin{array}{r}7.6 \mathrm{~b} \\
6.1 \mathrm{c} \\
7.3 \mathrm{~b} \\
10.8 \mathrm{a}\end{array}$ & $\begin{array}{r}8.9 \mathrm{~b} \\
7.7 \mathrm{c} \\
9.2 \mathrm{~b} \\
14.8 \mathrm{a}\end{array}$ \\
\hline & 25 & $\begin{array}{l}15 \\
20 \\
25 \\
30\end{array}$ & $\begin{array}{l}78 \mathrm{a} \\
82 \mathrm{a} \\
64 \mathrm{~b} \\
32 \mathrm{c}\end{array}$ & $\begin{array}{r}10.8 \mathrm{a} \\
7.9 \mathrm{~b} \\
8.2 \mathrm{~b} \\
10.8 \mathrm{a}\end{array}$ & $\begin{array}{r}11.2 \mathrm{~b} \\
9.6 \mathrm{c} \\
10.8 \mathrm{~b} \\
14.8 \mathrm{a}\end{array}$ \\
\hline \multirow[t]{2}{*}{$\begin{array}{l}\text { Magic Fountains } \\
\text { Lilac }\end{array}$} & 2 & $\begin{array}{l}15 \\
20 \\
25 \\
30\end{array}$ & $\begin{array}{l}83 \mathrm{a} \\
83 \mathrm{a} \\
72 \mathrm{~b} \\
11 \mathrm{c}\end{array}$ & $\begin{array}{c}7.9 \mathrm{~b} \\
6.4 \mathrm{c} \\
7.5 \mathrm{bc} \\
12.0 \mathrm{a}\end{array}$ & $\begin{array}{r}6.4 \mathrm{~b} \\
5.1 \mathrm{c} \\
6.8 \mathrm{~b} \\
11.3 \mathrm{a}\end{array}$ \\
\hline & 25 & $\begin{array}{l}15 \\
20 \\
25 \\
30\end{array}$ & $\begin{array}{l}82 \mathrm{ab} \\
86 \mathrm{a} \\
75 \mathrm{~b} \\
16 \mathrm{c}\end{array}$ & $\begin{array}{r}10.5 \mathrm{~b} \\
7.8 \mathrm{c} \\
9.4 \mathrm{~b} \\
14.2 \mathrm{a}\end{array}$ & $\begin{array}{r}8.3 \mathrm{~b} \\
6.8 \mathrm{c} \\
8.2 \mathrm{~b} \\
13.0 \mathrm{a}\end{array}$ \\
\hline
\end{tabular}

${ }^{\mathrm{z}}$ Values represent the means of 400 seeds.

${ }^{\mathrm{y}}$ Mean separation within each column among germination temperatures by Tukey's studentized range test $(P<0.05)$. 


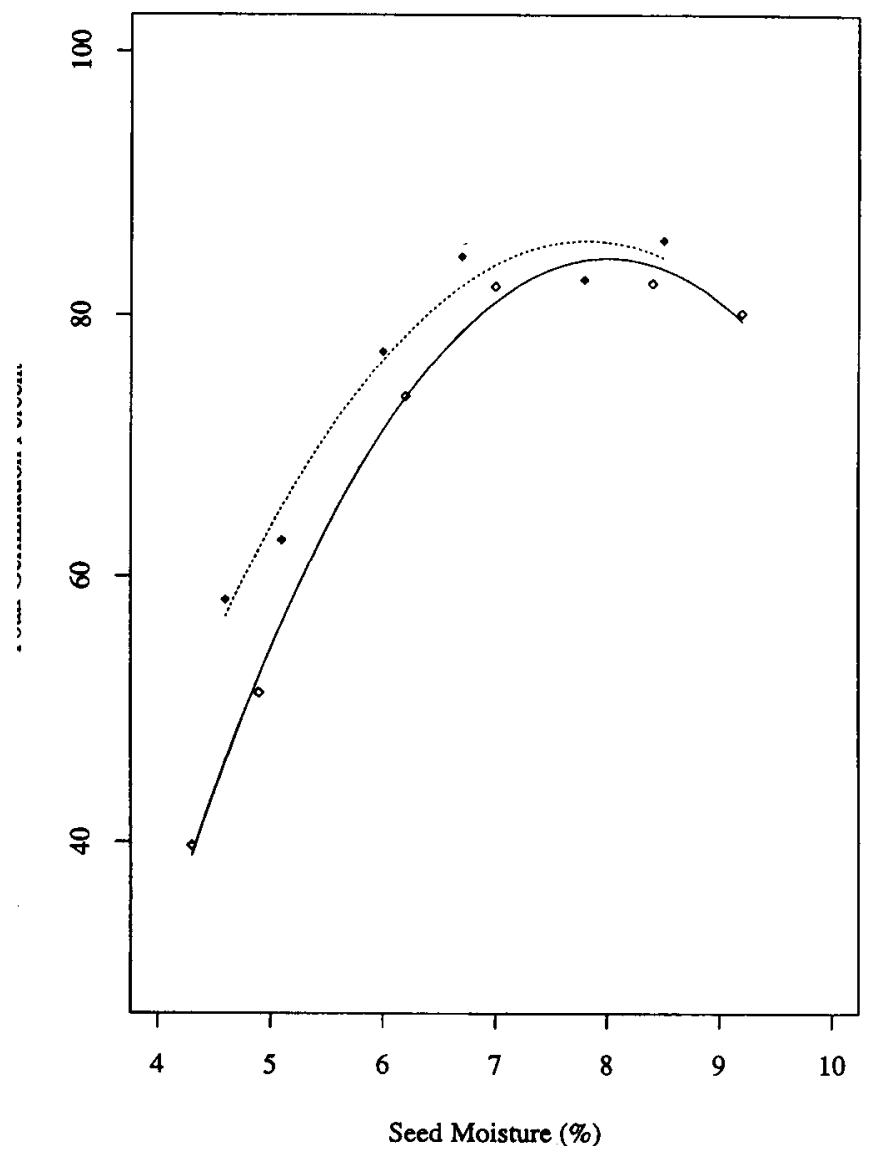

Fig. 1. Relationship between seed moisture content during storage and the subsequent total germination percentage $(G)$ of delphinium 'Magic Fountains Lavender' $(\diamond-)$ and 'Magic Fountains Lilac' $(\diamond \cdots . .$.$) . Comparisons were made using polynomial regression analyses at P=0.05$. "Magic Fountains Lavender': $\hat{G}=-127.50+52.95 \times$ moisture $-3.31 \times$ moisture $^{2}, R^{2}=0.94$. 'Magic Fountains Lilac': $\hat{G}=-83.60+43.31 \times$ moisture $-2.78 \times$ moisture ${ }^{2}, R^{2}=0.86$.

Table 2. Delphinium seed germination at $20 \mathrm{C}$ and under 12 -h alternating temperatures following 6 weeks storage at $2 \mathrm{C}$.

\begin{tabular}{lcccc}
\hline & & \multicolumn{3}{c}{ Germination } \\
\cline { 3 - 5 } Cultivar & $\begin{array}{c}\text { Temp } \\
\left({ }^{\circ} \mathrm{C}\right)\end{array}$ & Percent & $\begin{array}{c}\mathrm{T}_{30} \\
(\text { days) }\end{array}$ & $\begin{array}{c}\mathrm{T}_{90}-\mathrm{T}_{\mathbf{2 0}} \\
\text { (days) }^{\mathbf{x}}\end{array}$ \\
\hline Magic Fountains Lavender & 20 & 82 & 6.4 & 6.3 \\
& $10-20$ & 84 & 7.5 & 6.8 \\
& $15-25$ & 85 & 7.3 & 7.1 \\
Tukey's HSD, 5\% & $20-30$ & 83 & 8.1 & 7.7 \\
Magic Fountains Lilac & & $\mathrm{NS}$ & 0.6 & 0.7 \\
& 20 & 85 & 6.6 & 5.2 \\
& $10-20$ & 89 & 7.8 & 5.8 \\
Tukey's HSD, 5\% & $15-25$ & 87 & 7.3 & 6.0 \\
& $20-30$ & 85 & 8.0 & 7.9 \\
\hline
\end{tabular}

'Except for 20C, temperature alternated every $12 \mathrm{~h}$.

yeans to $50 \%$ of final germination.

'Days from $10 \%$ to $90 \%$ germination.

were weighed, dehydrated at $105 \mathrm{C}$ for $48 \mathrm{~h}$, and reweighed after cooling to determine the initial moisture content.

Storage temperature. Treatments consisting of four 100-seed replicates were placed in $15 \times 2.5-\mathrm{cm}$ petri dishes on wire screens supported by segments of tubing $1 \mathrm{~cm}$ above a chemical desiccant. Constant RH $(22 \%)$ was maintained in the dishes sealed with parafilm after $50 \mathrm{ml}$ of saturated potassium acetate was added to the bottom of each dish (Copeland, 1976). Refrigerated incubators were maintained at $2 \mathrm{C}$ for 2 weeks, then actions during seed storage. Seeds of 'Magic Fountains Lavender' were stored at $11 \%$, $34 \%, 52 \%, 75 \%$, or $95 \% \mathrm{RH}$ at 5,15 , or $25 \mathrm{C}$ for $3,6,9$, or 12 months. Humidity treatments were achieved as described previously, except saturated lithium chloride, magnesium chloride, magnesium nitrate, sodium chloride, or potassium nitrate maintained $11 \%, 34 \%, 52 \%, 75 \%$, or $95 \% \mathrm{RH}$, respectively. Incubators maintained constant temperatures during seed storage or germination. Four 100-seed replications were germinated at $20 \mathrm{C}$ in darkness immediately following storage at each duration and $\mathrm{RH}$ level, while another four replications were desiccated in force-draft ovens for $48 \mathrm{~h}$ at $105 \mathrm{C}$ to determine the moisture contents of stored seed. Analysis of variance and response surface regression procedures were used to analyze the data. Within each storage temperature, a randomized complete block design was used with a factorial treatment structure $(4 \times 5)$ between relative humidity and storage period.

Temperature influenced seed germination, with $\mathrm{G}$ generally higher at a constant 15 or $20 \mathrm{C}$ than at 25 or $30 \mathrm{C}$ (Table 1). Mean $\mathrm{T}_{50}$ and $\mathrm{T}_{90}-\mathrm{T}_{10}$ generally were shorter at $20 \mathrm{C}$ than at 15,25 , or $30 \mathrm{C}$. Our results indicated that $20 \mathrm{C}$ promoted faster and more uniform germination of delphinium and that the seeds germinated over a broad temperature range, as reported by the U.S. Dept. of Agriculture (1961). No differences in $G$ were found among seeds receiving alternating temperatures at $12-\mathrm{h}$ intervals or at a constant $20 \mathrm{C}$ (Table 2). Shorter $\mathrm{T}_{\mathrm{so}}$ occurred at constant $20 \mathrm{C}$ than at alternating $10 / 20 \mathrm{C}, 15 / 25 \mathrm{C}$, or 20/30C. The germination spans were similar for seeds at constant $20 \mathrm{C}$ or alternating $10 /$ $20 \mathrm{C}$ but longer at $15 / 25 \mathrm{C}$ and $20 / 30 \mathrm{C}$ (Table 2). Hartmann et al. (1990) reported fluctuating day/night temperatures increased seed germination, with optimal diurnal variations of 10C. Our results indicated that the germination of delphinium was not increased by 12-h alternating temperatures.

Storing seed dry for 3 weeks at 2 or $25 \mathrm{C}$ failed to change the $\mathrm{G}$ at $15,20,25$, or $30 \mathrm{C}$ germination temperatures (Table 1). Seeds stored at $2 \mathrm{C}$ for 3 weeks generally had significantly reduced $T_{5} 0$ and $T_{90}-T_{10}$ for both cultivars (Table 1). Although Ball (1985) recommended chilling delphinium seed before sowing, no indication was given as to the nature or extent of the benefit.

Seed had only limited desiccation tolerance. 'Magic Fountains Lavendar' seeds had 9.2\% moisture and 'Magic Fountains Lilac' $8.4 \%$ moisture when received. Reducing 'Magic Fountains Lavender' seed moisture below $7.0 \%$ or 'Magic Fountains Lilac' moisture below $6.7 \%$ significantly lowered total germination (Fig. 1). Bewley and Black (1982) suggested that embryo cells are damaged during severe seed dehydration, especially the tonoplast and plasmalemma, both selectively permeable membranes. The capacity of seeds to maintain physiological integrity during dry storage and regain a high level of metabolism upon rehydration is a determining factor in seed vigor or viability. 
Table 3. Coefficient estimates, $R^{2}$ values, and figure designations for the second-degree models; estimated response $=b_{0}+b_{1} P$ $+b_{2} R H+b_{3} P \times R H+b_{4} P^{2}+b_{5} R^{2}$.

\begin{tabular}{|c|c|c|c|c|c|c|c|c|c|}
\hline \multirow[b]{2}{*}{ Response } & \multirow{2}{*}{$\begin{array}{c}\text { Temp } \\
\left({ }^{\circ} \mathrm{C}\right)\end{array}$} & \multicolumn{6}{|c|}{ Coefficient estimates } & \multirow[b]{2}{*}{$R^{2}$} & \multirow[b]{2}{*}{ Figure } \\
\hline & & $\mathrm{b}_{0}$ & $\mathrm{~b}_{1}$ & $b_{2}$ & $b_{3}$ & $b_{4}$ & $b_{s}$ & & \\
\hline $\bar{G}$ & $\begin{array}{r}5 \\
15 \\
25\end{array}$ & $\begin{array}{l}63.2 \\
92.8 \\
76.8\end{array}$ & $\begin{array}{l}-3.4 \\
-7.7 \\
-4.5\end{array}$ & $\begin{array}{l}1.7 \\
0.9 \\
0.8\end{array}$ & $\begin{array}{l}0.04 \\
0.001 \\
0.09\end{array}$ & $\begin{array}{l}0.009 \\
0.37 \\
0.03\end{array}$ & $\begin{array}{l}-0.03 \\
-0.02 \\
-0.02\end{array}$ & $\begin{array}{l}0.78 \\
0.81 \\
0.93\end{array}$ & $\begin{array}{l}3 A \\
3 B \\
3 C\end{array}$ \\
\hline $\mathrm{T}_{50}$ & $\begin{array}{r}5 \\
15 \\
25\end{array}$ & $\begin{array}{r}9.1 \\
8.9 \\
15.0\end{array}$ & $\begin{array}{r}0.26 \\
0.51 \\
-0.37\end{array}$ & $\begin{array}{l}-0.12 \\
-0.13 \\
-0.37\end{array}$ & $\begin{array}{r}-0.11 \\
-0.04 \\
0.03\end{array}$ & $\begin{array}{l}0.003 \\
0.004 \\
0.003\end{array}$ & $\begin{array}{l}0.001 \\
0.001 \\
0.006\end{array}$ & $\begin{array}{l}0.56 \\
0.47 \\
0.87\end{array}$ & $\begin{array}{l}3 \mathrm{D} \\
3 \mathrm{E} \\
3 \mathrm{~F}\end{array}$ \\
\hline$T_{90}-T_{10}$ & $\begin{array}{r}5 \\
5 \\
15 \\
25\end{array}$ & $\begin{array}{r}8.5 \\
8.2 \\
13.7\end{array}$ & $\begin{array}{c}0.3 \\
0.6 \\
-0.26\end{array}$ & $\begin{array}{l}-0.08 \\
-0.09 \\
-0.24\end{array}$ & $\begin{array}{r}-0.02 \\
-0.04 \\
0.03\end{array}$ & $\begin{array}{r}0.002 \\
0.005 \\
-0.004\end{array}$ & $\begin{array}{l}0.008 \\
0.001 \\
0.005\end{array}$ & $\begin{array}{l}0.46 \\
0.56 \\
0.72\end{array}$ & $\begin{array}{l}3 \mathrm{G} \\
3 \mathrm{H} \\
3 \mathrm{I}\end{array}$ \\
\hline
\end{tabular}

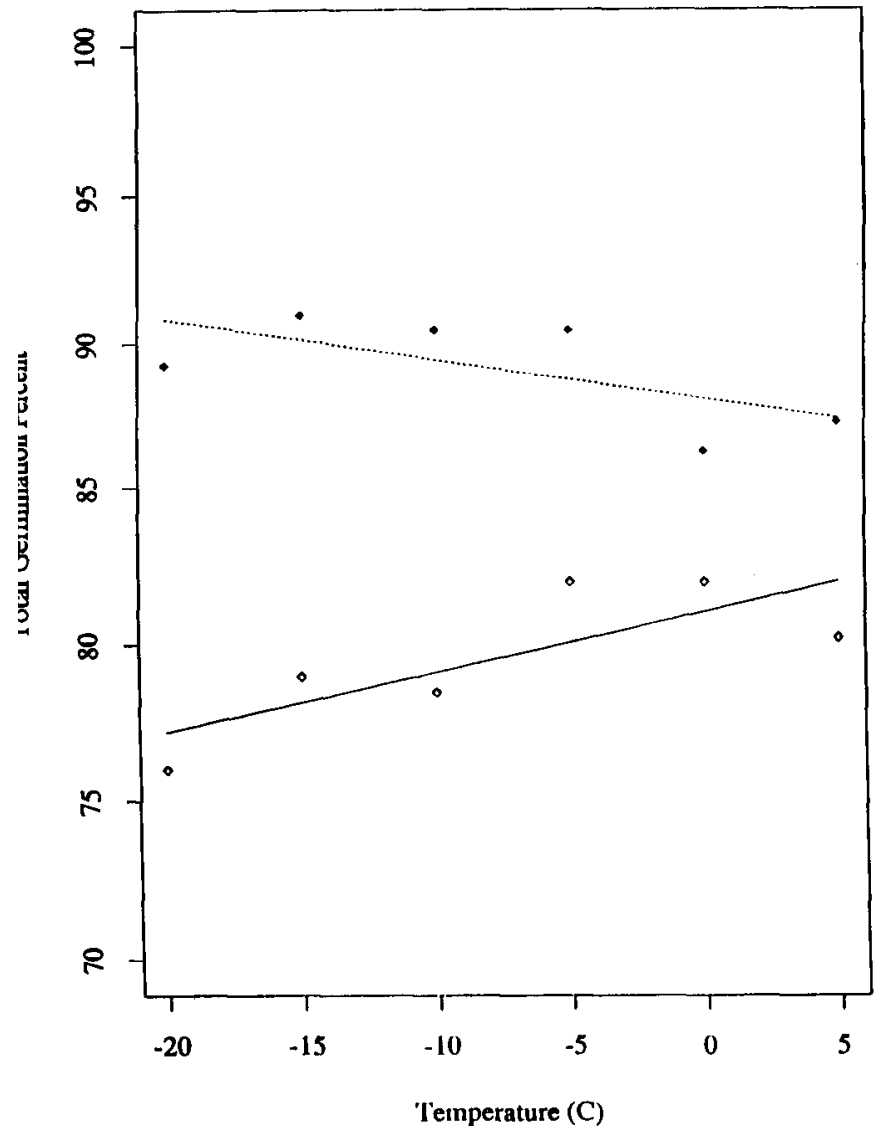

Fig. 2. Effect of seed storage at low, nonfreezing and subzero temperatures on the total germination percentage $(G)$ of delphinium 'Magic Fountains Lavender' $(\diamond-)$ and 'Magic Fountains Lilac' $(\$ \cdots . .$.$) . Data were analyzed by linear regression analysis (P=0.05)$. 'Magic Fountains Lavender': $\hat{\mathrm{G}}=81.07-0.19 \times$ temp, $R^{2}=0.24$. 'Magic Fountains Lilac': $\hat{\mathrm{G}}=88.09-0.14$ $\times$ temp, $R^{2}=0.20$.

The seeds of both cultivars were tolerant of low, nonfreezing and subzero storage temperatues, but the cultivars responded differently to low temperatures during germination (Fig. 2). 'Magic Fountains Lavender' germination declined with storage temperatures between 5 to $-20 \mathrm{C}$, while that of 'Magic Fountains Lilac' increased as temperatures declined. 'Magic Fountains Lavender' had higher seed moisture $(7.8 \%)$ than 'Magic Fountains Lilac (6.9\%) during freezing, which possibly contributed to the reduced germination.

The RH and temperature during seed storage determined the total germination after storage. Highest total germination occurred after $5 \mathrm{C}$ storage at $30 \%$ to $50 \% \mathrm{RH}$, although germination percentage declined at long storage durations (Fig. 3A). Total germination percentages declined when RH was above or below the $30 \%$ to $50 \%$ range. Storing seeds at $15 \mathrm{C}$ generally led to lower $\mathrm{G}$ than storage at 5C (Fig. 3B). Highest total germination at $15 \mathrm{C}$ was at $25 \% \mathrm{RH}$, although differences among treatments between $10 \%$ and $40 \%$ RH were small. Larger losses in seed viability at $15 \mathrm{C}$ than at $5 \mathrm{C}$ occurred above $60 \% \mathrm{RH}$. Seeds stored at $25 \mathrm{C}$ had lower total germination after storage than those stored at 5 or $15 \mathrm{C}$ at all relative humidity levels (Fig. 3C)

Seeds achieved $\mathrm{T}_{50}$ in fewer days after storage at $5 \mathrm{C}$ than at 15 or $25 \mathrm{C}$ (Fig. 3D$\mathrm{F})$. Germination $\mathrm{T}_{50}$ required fewest days after $5 \mathrm{C}$ storage at $35 \%$ to $55 \% \mathrm{RH}$, with longer periods required at higher or lower RH levels
(Fig. 3D). At $15 \mathrm{C}$, shortest periods to $\mathrm{T}_{50}$ occurred after $25 \%$ to $50 \% \mathrm{RH}$ seed storage, but differences in $\mathrm{T}_{50}$ among relative humidities were small, except above $70 \%$ (Fig. 3E). Storing seeds at $25 \mathrm{C}$ delayed germination by lengthening $\mathrm{T}_{50}$ values, with longest delays for seeds stored above $50 \%$ RH (Fig. 3F).

The $\mathrm{T}_{90}-\mathrm{T}_{10}$ values generally were lengthened by storing seeds at high temperatures and high relative humidities (Fig. 3GI). Although fewer days to $\mathrm{T}_{90}-\mathrm{T}_{10}$ were required after storage at $5 \mathrm{C}$ than at $15 \mathrm{C}$, both had uniform germination spans below $40 \%$ RH (Fig. $3 \mathrm{G}$ and H). At 25C, the relative humidity level during seed storage governed the length of $\mathrm{T}_{90}-\mathrm{T}_{10}$ (Fig. 31). Relative humidity level during seed storage at $25 \mathrm{C}$ had more effect on $\mathrm{G}, \mathrm{T}_{50}$, or $\mathrm{T}_{90}-\mathrm{T}_{10}$ than on extending the storage period from 3 to 12 months (Fig. 3A-I).

This study presents information for optimizing the environmental conditions during the storage and germination of delphinium seed. The seed had no requirement for light or darkness to terminate germination and had similar $\mathrm{G}$ and $\mathrm{T}_{50}$ (data not presented) for seed germinated at $20 \mathrm{C}$ in darkness or in 24 $\mathrm{h}$ irradiation (60-W incandescent lamps at 75 $\left.\mu \mathrm{mol} \cdot \mathrm{m}^{-2} \cdot \mathrm{s}^{-1}\right)$. Highest $\mathrm{G}$ occurred at a constant 15 or $20 \mathrm{C}$, germination temperatures recommended in earlier reports. Similar $\mathrm{G}$ and frequently shorter $\mathrm{T}_{50}$ or $\mathrm{T}_{90}$ $\mathrm{T}_{10}$ were found among seeds germinated at a constant $20 \mathrm{C}$ than at alternating (12 h) $10 /$ 20C, $15 / 25 \mathrm{C}$, or 20/30C. Carpenter and Ostmark (1988) and Carpenter et al. (1991) reported amaryllis (Hippeastrum $\times$ hybridum Hort) and gladiolus (Gladiolus grandiflorous Andr.) had maximum $\mathrm{G}$ at optimum constant temperatures and significantly lower levels at 12 -h alternating temperatures.

Our research reaffirmed that storing delphinium seeds dry at $2 \mathrm{C}$ promoted improved germination after storage (Ball, 1985). Storing seeds dry at $2 \mathrm{C}$, rather than $25 \mathrm{C}$, promoted both earlier $T_{50}$ and shorter $T_{90}-T_{10}$. No differences were found between the $\mathrm{G}$, $\mathrm{T}_{\mathrm{s}}$, or $\mathrm{T}_{90}-\mathrm{T}_{10}$ of seeds stored at 2 and $5 \mathrm{C}$ for 5 weeks (data not presented). Delphinium seeds were tolerant of low, nonfreezing and subzero temperatures during storage at $6.9 \%$ moisture content. Barton (1932) reported that annual and perennial delphinium seed had no significant loss in $\mathrm{G}$ or vigor after storage for 5 years at $-15 \mathrm{C}$.

Improved practices and technology in the seed production industry have promoted the 

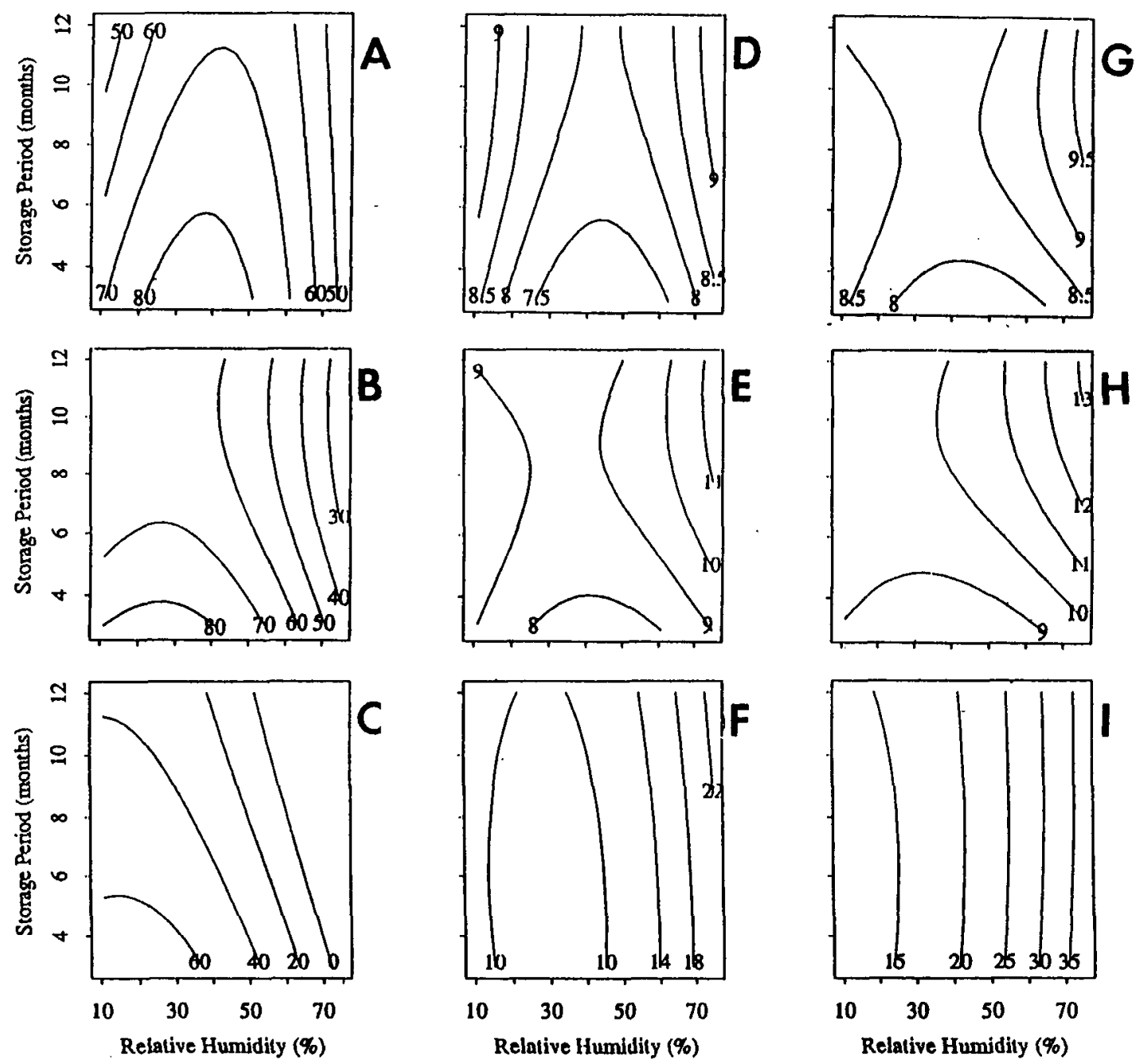

Fig. 3. Contour plots for total germination percentages (A-C), days to $50 \%$ of final germination (D-F), and days between $10 \%$ and $90 \%$ germination (GI) for seeds germinated at $20 \mathrm{C}$ following storage at $11 \%$ to $95 \% \mathrm{RH}$ for 3 to 12 months at $5 \mathrm{C}(\mathbf{A}, \mathbf{D}, \mathbf{G}), 15 \mathrm{C}(\mathbf{B}, \mathbf{E}, \mathbf{H})$, or $25 \mathrm{C}(\mathbf{C}, \mathbf{F}, \mathbf{I})$. Regression equations used to generate these plots are listed in Table 3.

drying of freshly harvested seeds to very low moisture levels for storage and shipment in sealed packages. It is very important to know whether drying causes losses in seed viability or vigor. Our study showed that a significant decline in G occurred when delphinium seed moisture contents declined below $6.7 \%$ to $7.0 \%$, which indicated the importance of controlling and limiting the moisture loss from the seed. Although the data are not presented, significant lengthening of $\mathrm{T}_{50}$ and $\mathrm{T}_{90}-\mathrm{T}_{10}$ also occurred as seed moisture leyels declined below $6.7 \%$ to $7.0 \%$. Justice and Bass (1978) reported that delayed and irregular germination are the first indications of seed injury from storage at excessively low moisture contents.

Seed moisture content during storage affects the rate of seed deterioration. In storage, the moisture content of seeds will come to equilibrium with the RH of the surrounding air. Delphinium seed stored 12 months at $5 \mathrm{C}$ and $11 \%, 34 \%, 52 \%, 75 \%$, or $95 \%$ RH had $4.9 \%, 6.8 \%, 8.3 \%, 11.1 \%$, and $15.4 \%$ moisture contents, respectively. Ac- cording to computer-generated estimates, the highest $\mathrm{G}$ occurred following seed storage at 5C and $30 \%$ to $50 \% \mathrm{RH}$, which resulted in $-6.6 \%$ to $8.2 \%$ seed moisture content. Shortest $\mathrm{T}_{50} \mathrm{~s}$ were after $5 \mathrm{C}$ storage at $35 \%$ to $55 \% \mathrm{RH}$, or $6.8 \%$ to $8.5 \%$ moisture contents, and shortest $\mathrm{T}_{90}-\mathrm{T}_{10}$ after $5 \mathrm{C}$ storage at $25 \%$ to $50 \% \mathrm{RH}$, or $\approx 6.1 \%$ to $8.2 \%$ seed moisture.

\section{Literature Cited}

Ball, V. 1985. Ball red book: Greenhouse growing. 14th ed. Reston Publishing Co., Reston, Và.

Barton, L.V. 1932. Effect of storage on the viability of delphinium seeds. Boyce Thompson Inst. Contrib. 4:141-153.

Bewley, J.D. and M. Black. 1982. Physiology and biochemistry of seeds. Springer-Verlag, New York.

Carpenter, W.J. and E.R. Ostmark. 1988. Sensitivity of seed germination of amaryllis to ligh and temperature. HortScience 23:1002-1004.

Carpenter, W.J., G.J. Wilfret, and J.A. Cornell. 1991. Temperature and relative humidity govern germination and storage of gladiolus seed.
HortScience 26:1054-1057.

Copeland, L.O. 1976. Principles of seed science and technology. Burgess, Minneapolis,

Furutani, S.C., B.H. Zandstra, and H.C. Price. 1985. Low temperature germination of celery seeds for fluid drilling. J. Amer. Soc. Hort. Sci. 110:149-153

Guy, C.L. and J.V. Carter. 1984. Characterization of partially purified glutathione reductase from cold hardened and nonhardened spinach leaf tissue. Cryobiology 21:454-464.

Hartmann, H.T., D.E. Kester, and F.T. Davies, Jr. 1990. Plant propagation principles and practices. 5th ed. Prentice Hall, Englewood Cliffs, N.J.

Holcomb, E.J. and D.J. Beattie. 1990. Potted delphiniums. Grower Talks 8:14-15.

Justice, O.L. and L.N. Bass. 1978. Principles and practices of seed storage. U.S. Dept. Agr. Hdbk. 506, Washington, D.C.

Post, K. 1942. Effects of daylength and temperature on growth and flowering of some florist crops. Cornell Agr. Expt. Sta. Bul. 787:1-70.

U.S. Dept. of Agriculture. 1961. Seeds. The yearbook of agriculture. U.S. Dept. Agr., Washington, D.C. 